\title{
UJI ANTIBAKTERI EKSTRAK DAN FRAKSI SPONS TERHADAP Escherichia coli DAN Staphylococcus aureus SERTA POTENSINYA TERHADAP AKTIVITAS ANTI-UV
}

\author{
(Antibacterial Assay of sponges extract and fraction against Escherichia coli and \\ Staphylococcus aureus bacteria and its potential for anti-uv activity)
}

\author{
Monika Gabrielle $^{1^{\star}}$, Deiske A. Sumilat ${ }^{1}$, Veibe Warouw ${ }^{1}$, Remy E. P. Mangindaan ${ }^{1}$, \\ Chatrien A. C. Sinjal ${ }^{1}$, Sammy N. J. Longdong ${ }^{2}$
}

1. Program Studi IImu Kelautan, FPIK, UNSRAT

2. Program Studi Budidaya Perairan, FPIK, UNSRAT

*e-mail : monikagabrielleakay@gmail.com

Abstract

Sponge organisms produce bioactive compounds that are toxic as a means of selfdefense. The compound is known to have the potential as an antibacterial and anti-UV which can absorb sunlight with the potential to be used as a material for making sunscreen. The purpose of this study was to obtain antibacterial activity against Escherichia coli and Staphylococcus aureus bacteria and anti-UV activity from crude extracts and sponges fractions. The antibacterial test done by agar diffusion method (Kirby and Bauer diffusion disc) and the crude extract and the active fraction of antibacterial compounds were tested in a UV spectrophotometer to see its antiUV activity. As a result, 4 species of sponges were extracted and partitioned into water fractions, methanol fractions, and $\mathrm{n}$-hexane fractions. All samples were tested for antibacterial activity and the results showed antibacterial activity against $S$. aureus by Plakortis sp. in crude extract $(9 \mathrm{~mm})$ and water fraction $(8.6 \mathrm{~mm})$, Agelas $\mathrm{sp}$. in crude extract $(7 \mathrm{~mm})$ and in E. coli bacteria shown by Plakortis $\mathrm{sp}$. in crude extract $(12.6 \mathrm{~mm})$ and water fraction $(9 \mathrm{~mm})$, Liosina $\mathrm{sp}$. in the water fraction $(7.6 \mathrm{~mm})$, Haliclona sp. in the water fraction $(8 \mathrm{~mm})$ and Agelas sp. in crude extract (10.3 $\mathrm{mm})$. Crude extracts and water fractions were tested using a UV spectrophotometer for anti-UV testing, the results showed that crude extract and all the water fractions of four species sponge could absorb UV-B ( $\lambda$ 290-320 nm) and UV-A ( $\lambda$ 320-400 nm).

Keywords: sponges, antibacterial, partition, anti-UV

\begin{abstract}
Abstrak
Organisme spons menghasilkan senyawa bioaktif yang bersifat toksik sebagai alat pertahanan diri. Senyawa tersebut diketahui memiliki potensi sebagai antibakteri dan anti-UV yang merupakan senyawa yang dapat menyerap sinar matahari dengan potensi dipakai sebagai bahan pembuatan tabir surya. Tujuan dari penelitian ini yaitu untuk mendapatkan aktivitas antibakteri terhadap bakteri Escherichia coli dan Staphylococcus aureus dan aktivitas anti-UV dari ekstrak kasar dan fraksi spons. Pengujian antibakteri dilakukan dengan metode difusi agar (disc diffusion Kirby and Bauer) dan ekstrak kasar spons dan fraksi yang aktif senyawa antibakterinya diujikan dalam UV spektofotometer untuk melihat aktivitas anti-UV. Dari hasil penelitian didapatkan 4 jenis spons yang diekstrak dan dipartisi menjadi fraksi air, fraksi metanol dan fraksi n-heksana. Seluruh sampel diuji aktivitas antibakterinya dan hasilnya menunjukkan aktivitas antibakteri terhadap bakteri $S$. aureus oleh spons jenis Plakortis sp. pada sampel ekstrak kasar (9 mm) dan fraksi air $(8,6 \mathrm{~mm})$, Agelas sp. pada sampel ekstrak kasar $(7 \mathrm{~mm})$ dan pada bakteri $E$. coli ditunjukkan oleh Plakortis sp. pada sampel ekstrak kasar $(12,6 \mathrm{~mm})$ dan fraksi air (9 mm), Liosina sp. pada fraksi air $(7,6 \mathrm{~mm})$, Haliclona sp. pada fraksi air $(8 \mathrm{~mm})$ dan Agelas sp. pada sampel ekstrak kasar (10,3 mm). Ekstrak kasar dan fraksi air yang ditemukan aktif dalam pengujian antibakteri diuji menggunakan UV spektrofotometer untuk pengujian antiUV, hasil menunjukkan bahwa sampel ekstrak kasar dan fraksi air keempat jenis spons dapat menyerap UV-B $(\lambda$ 290-320 nm) dan UV-A $(\lambda$ 320-400 nm).
\end{abstract}

Kata kunci: spons, antibakteri, partisi, anti-UV 


\section{PENDAHULUAN}

Indonesia sebagai negara yang memiliki keanekaragaman hayati laut tinggi di dunia yang menjadi tempat tinggal bagi banyak sekali organisme laut (Marzuki, 2018). Organisme laut seperti moluska, tunikata, spons dan bryozoa telah diteliti menghasilkan senyawa bioaktif seperti alkaloid, peptida, poliketida, dll yang berpotensi sebagai bahan baku obatobatan (Thakur dan Muller, 2004).

Di Indonesia sudah teridentifikasi sebanyak 850 jenis dan berpotensi untuk ditemukan senyawa bioaktifnya (Warbung, 2013). Berdasarkan studi-studi yang telah dilakukan sebelumnya terhadap organisme spons, organisme ini menunjukkan adanya aktivitas farmakologis seperti antibakteri, antifungi, antiviral, anti-inflamasi, antivirus, antikanker, dll (Mehbub, dkk 2014). Hasil metabolit sekunder dari spons sangat menarik untuk diteliti karena memiliki potensi yang besar untuk dikembangkan dalam bidang farmasi salah satunya sebagai antibakteri (Murniasih, 2003). Demikian pula ditemukan senyawa antiUV yang berupa turunan asam amino

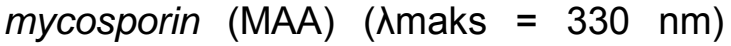
pada spons yang dapat menyerap paparan sinar UV-A (Bandaranayake $d k k$, 1996). Pembentukan senyawa mycosporin merupakan hasil pertahanan tubuh yang dilakukan organisme terhadap radiasi sinar matahari (Warouw dan Losung, 2015).

Adapun dalam penelitian ini pengujian antibakteri akan menggunakan bakteri gram (-) yaitu Escherichia coli dan bakteri gram (+) Staphylococcus aureus. Menurut Melliawati (2015) E. coli merupakan bakteri yang masuk kemulut melalui tangan yang dapat menyebabkan gastroenteristis (peradangan usus) pada manusia. Sedangkan $S$. aureus merupakan bakteri yang masuk ke aliran darah manusia dan menyebabkan berbagai infeksi seperti, infeksi endokarium (lapisan dalam jantung), infeksi tulang dan radang sendi (Archer, 1998).

Lokasi penelitian di Perairan Pangalisang Bunaken sering mengalami gangguan seperti sedimentasi tinggi dan banyaknya aktivitas wisata. Melihat kondisi yang demikian, maka organisme spons harus beradaptasi dengan lingkungannya, bentuk adaptasi dari spons adalah dengan menghasilkan metabolit sekunder yang perlu dieksplorasi khususnya untuk menemukan senyawa bioaktif, khususnya dalam penelitian ini organisme spons akan diekstrak dan dipartisi untuk diuji aktivitas antibakteri melalui zona hambat dan antiUV melalui serapan panjang gelombang menggunakan UV spektrofotometer.

\section{METODE PENELITIAN}

\section{Waktu dan Tempat Penelitian}

Sampel spons diperoleh dari perairan Pangalisang Bunaken melalui penyelaman (skin dive) dengan menggunakan satu set alat snorkeling pada kedalaman sekitar 3-7 meter. Sampel selanjutnya dibawa ke Laboratorium Biologi Molekuler dan Farmasetika Laut, FPIK UNSRAT untuk diteliti aktivitas antibakteri dan Laboratorium Kimia Analisis Farmasi, FMIPA UNSRAT untuk pengujian aktivitas anti-UV menggunakan alat UV Spektrofotometer.

\section{Pengambilan Sampel dan Identifikasi}

Pengambilan sampel spons
dilakukan dengan cara memotong
organisme spons langsung dari
substratnya sekitar 100-500 gr sebanyak
4 jenis. Sampel yang diperoleh
diidentifikasi dengan membandingkan
morfologinya (bentuk, warna dan tekstur)
berdasarkan pedoman dari Gosliner dkk
(1996) dan Allen dkk (2007).

\section{Alat dan Bahan}

Peralatan yang digunakan penelitian ini adalah timbangan, botol evaporasi, satu set rotary vacuum evaporator, corong pisah, statif, klem, erlenmeyer, cawan petri, mikropipet, 
kertas cakram, laminar air flow, oven, autoklaf, mistar, spatula, aluminium foil dan UV spektrofotometer. Sedangkan bahan yang diperlukan adalah 4 jenis spons, pelarut etanol 95\%, aquadest, metanol, etil asetat, n-heksana, kloramfenikol, $\mathrm{NaCl}$, pepton, agar dan ekstrak daging.

\section{Sterilisasi Alat dan Bahan}

Alat-alat yang digunakan untuk pengujian antibakteri pada penelitian ini seperti tabung reaksi, cawan petri, erlenmeyer, dan beberapa peralatan lainnya dicuci bersih, dikeringkan dan dibungkus dengan kertas dan dimasukkan ke dalam oven selama 2 jam pada suhu $150^{\circ} \mathrm{C}$ (sterilisasi kering).

\section{Ekstraksi}

Sampel spons yang telah dibersihkan, dipotong kecil dan dimaserasi di dalam botol yang sudah diberikan label dan berisi etanol 95\% sebanyak $200 \mathrm{ml}$ selanjutnya ditimbang menggunakan timbangan. Maserasi dilakukan selama $1 \mathrm{x}$ 24 jam dengan $3 x$ ulangan. Setelah itu dipisahkan filtrat dan debris. Hasil filtrat diuapkan menggunakan rotary vacuum evaporator pada suhu $40^{\circ} \mathrm{C}$ hingga diperoleh ekstrak kasar.

\section{Partisi}

Ekstrak kasar dari sampel spons akan dipartisi menggunakan metanol, etil asetat dan n-heksana dan air dengan hasil akhir partisi sebanyak 3 fraksi, yaitu fraksi air (polar), fraksi metanol (semipolar) dan fraksi n-heksana (non-polar). Pertama, pelarut air (polar) sebanyak 100 $\mathrm{ml}$ dituang ke dalam corong pisah dan diikuti oleh ekstrak kasar sebanyak $10 \mathrm{gr}$, selanjutnya dicampur dengan pelarut etil asetat (semi-polar) $100 \mathrm{ml}$. Perbandingan pelarut dalam corong pisah adalah (1:1), kemudian kocok corong pisah dan diamkan selama beberapa saat sampai dua larutan terpisah membentuk 2 lapisan. Ketika kedua pelarut sudah terpisah, kran corong pisah dibuka dan pelarut yang paling bawah ditampung pada erlenmeyer sehingga didapatkan fraksi pertama yaitu fraksi air (air berada di lapisan bawah karena berat jenisnya lebih berat dari etil asetat). Selanjutnya pelarut yang berada di atas fraksi air yaitu fraksi etil asetat ditampung ke dalam erlenmeyer yang berbeda.

Fraksi etil asetat selanjutnya dievaporasi. Kegiatan partisi selanjutnya dilakukan dengan menuangkan pelarut metanol (semi-polar) $100 \mathrm{ml}$ ke dalam corong pisah dan diikuti oleh hasil evaporasi etil asetat, kemudian ditambahkan pelarut n-heksana (nonpolar) $100 \mathrm{ml}$. Setelah terbentuk lapisan, kran corong pisah dibuka dan ditampung lapisan pertama, yaitu fraksi metanol pada erlenmeyer, kemudian lapisan di atas yaitu fraksi $n$-heksana ditampung pada erlenmeyer berbeda. Fraksi air, metanol dan n-heksana masing-masing dievaporasi untuk selanjutnya dipakai dalam uji antibakteri dan anti-UV.

\section{Media Cair B1}

Media cair B1 dibuat sebanyak 2 media atau 2 erlenmeyer untuk kultur bakteri uji. Banyaknya bahan untuk membuat media cair B1 untuk satu erlenmeyer yaitu: pepton $0,25 \mathrm{~g}$, ekstrak daging (meat extract) $0,15 \mathrm{~g}$ dan $\mathrm{NaCl}$ $0,15 \mathrm{~g}$ dan dilarutkan dalam aquadest sebanyak $50 \mathrm{ml}$, selanjutnya dihomogenkan menggunakan spatula, setelah itu ditutup dan dibungkus menggunakan aluminium foil lalu disterilkan dalam autoklaf pada suhu $121^{\circ}$ C selama kurang lebih 15 menit.

\section{Kultur Bakteri}

Bakteri uji E. coli dan S. aureus diperoleh dari di Laboratorium Biologi Molekuler dan Farmasetika Laut, Fakultas Perikanan dan IImu Kelautan Universitas Sam Ratulangi Manado. Untuk pengkulturan, bakteri E. coli dan S. aureus diambil menggunakan jarum ose dengan cara digerus dan dimasukkan ke dalam erlenmeyer yang telah berisikan media cair yang dibuat sebelumnya, kemudian dibungkus menggunakan kertas alumunium foil dan diinkubasi selama $1 \mathrm{x}$ 24 jam.

\section{Media Padat B1}


Media padat B1 dibuat sebanyak 2 erlenmeyer untuk 2 bakteri uji. Untuk 1 erlenmeyer diperlukan bahan-bahan seperti pepton $1 \mathrm{~g}$, ekstrak daging (meat extract) 0,6 g, NaCl 0,6 gram, agar 3 gram dan aquadest sebanyak $200 \mathrm{ml}$. Seluruh bahan dihomogenkan dan dibungkus dengan kertas alumunium foil lalu disterilkan menggunakan autoklaf pada suhu $121^{\circ} \mathrm{C}$ selama \pm 15 menit, selanjutnya media dibiarkan sampai hangat lalu masukkan bakteri yang telah dikultur dengan media cair B1 menggunakan mikropipet berukuran 1000 $\mu \mathrm{l}$ sebanyak $2 \mathrm{ml}$, kemudian ditutup kembali menggunakan alumunium foil dan diaduk perlahan, setelah itu dituang secukupnya (8-12 ml) ke dalam cawan petri yang sudah steril.

\section{Kontrol}

Untuk melihat ada tidaknya zona hambat atau aktivitas antibakteri dari sampel ekstrak kasar dan ketiga fraksi hasil partisi diperlukan kontrol positif dan negatif. Kontrol positif merupakan tolak ukur dalam mengamati diameter zona hambat yang dihasilkan oleh ekstrak sampel spons, dan kontrol negatif berfungsi untuk melihat apakah pelarut metanol memberikan pengaruh terhadap zona hambat ekstrak sampel atau tidak. Adapun pembuatan kontrol positif yaitu $100 \mathrm{mg}$ kloramfenikol dilarutkan dalam 1 $\mathrm{ml}$ metanol, dan untuk kontrol negatif digunakan pelarut metanol $95 \%$.

\section{Pengujian Antibakteri}

Pengujian antibakteri menggunakan konsentrasi ekstrak kasar spons 100 $\mathrm{mg} / \mathrm{ml}$ dan konsentrasi sampel dari fraksi air, metanol, dan $\mathrm{n}$ - heksana $10 \mathrm{mg} / \mathrm{ml}$ diambil masing-masing $20 \quad \mu l$ menggunakan mikropipet untuk ditotolkon pada kertas cakram berukuran $6 \mathrm{~mm}$ dengan daya serap $100 \mu \mathrm{l}$ tiap kertas cakram dan dimasukkan ke dalam wadah steril yang telah diberi tanda. Adapun banyaknya kertas cakram yang diperlukan adalah sebanyak 6 kertas cakram per cawan petri, dan untuk kedua bakteri uji dilakukan 3 kali ulangan untuk memastikan keakuratan data melalui pengukuran zona hambat.
Kertas cakram kemudian ditotol dan diletakkan di atas media padat B1 yang telah dibuat dalam cawan petri dan diberi label. Setelah itu, cawan petri ditutup dan diinkubasi selama 1 x 24 jam. Jika daerah sekitaran kertas cakram menunjukan adanya aktivitas antibakteri, maka akan terdapat zona hambat/ zona bening yang terbentuk di sekitar kertas cakram ekstrak kasar dan fraksi spons yang nantinya akan diukur diameternya dalam satuan $(\mathrm{mm})$ menggunakan mistar berskala.

\section{Pengujian Anti-UV}

Ekstrak dan fraksi spons yang akan diuji pada UV spektofotometer untuk mengetahui apakah organisme spons tersebut memiliki senyawa anti-UV. Pertama dilakukan pengenceran dimana 1 mg eksrak kasar dan fraksi spons diencerkan dengan metanol $20 \%$ sebanyak $100 \mathrm{ml}$ kemudian hasil pengenceran diambil sebanyak $4 \mathrm{ml}$ dimasukkan dalam suprasil kuvet, pada kuvet yang satunya dimasukkan pelarut metanol 20\% sebagai blanko (Luthfiyana $d k k, 2016)$. Kemudian diuji pada alat UV spektofotometer dengan rentang panjang gelombang 290-400 nm. Selanjutnya, diamati banyaknya sinar yang diabsorbsi.

\section{HASIL DAN PEMBAHASAN}

\section{Organisme Uji}
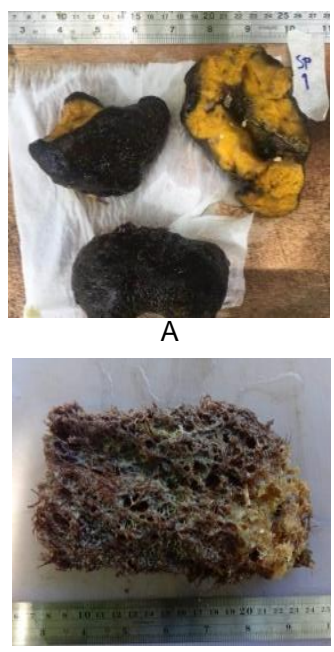

C

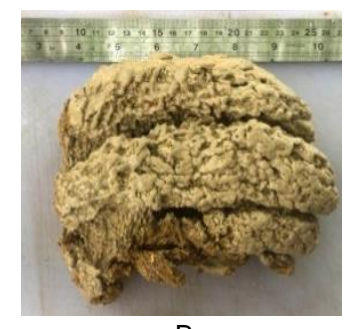

B

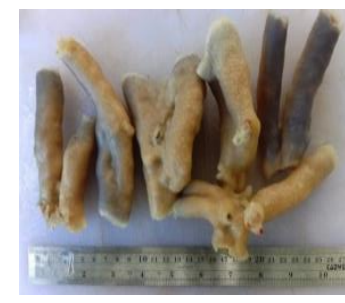

D

Gambar 1. (A) Plakortis sp., (B) Liosina sp., (C) Haliclona sp., (D) Agelas sp. 


\section{Ekstraksi}

Setelah dimaserasi sebanyak 3 kali dan dievaporasi, diperoleh ekstrak kasar kemudian ditimbang menggunakan timbangan analitik (Tabel 1).

Tabel 1. Berat sampel spons

\begin{tabular}{lcc}
\hline \multicolumn{1}{c}{ Spons } & $\begin{array}{c}\text { Berat } \\
\text { Basah }\end{array}$ & $\begin{array}{c}\text { Berat } \\
\text { Ekstrak }\end{array}$ \\
\hline Plakortis sp. (SPB 1) & $470 \mathrm{~g}$ & $27 \mathrm{~g}$ \\
\hline Liosina sp. (SPB 2) & $450 \mathrm{~g}$ & $26 \mathrm{~g}$ \\
\hline Haliclona sp. (SPB 3) & $124 \mathrm{~g}$ & $15 \mathrm{~g}$ \\
\hline Agelas sp. (SPB 4) & $100 \mathrm{~g}$ & $16 \mathrm{~g}$ \\
\hline
\end{tabular}

\section{Partisi}

Hasil ekstrak kemudian dipartisi dengan hasil akhir diperoleh 3 jenis fraksi, yaitu fraksi air, fraksi metanol dan fraksi nheksana. Masing-masing fraksi dievaporasi dan ditimbang menggunakan timbangan analitik (Tabel 2).

Tabel 2. Berat fraksi spons

\begin{tabular}{lccc}
\hline \multicolumn{1}{c}{ Spons } & $\begin{array}{c}\text { Fraksi } \\
\text { Air }\end{array}$ & $\begin{array}{c}\text { Fraksi } \\
\text { metanol }\end{array}$ & $\begin{array}{c}\text { Fraksi } \\
\text { n-heksana }\end{array}$ \\
\hline Plakortis sp. (SPB 1) & $4300 \mathrm{mg}$ & $1130 \mathrm{mg}$ & $310 \mathrm{mg}$ \\
\hline Liosina sp. (SPB 2) & $5100 \mathrm{mg}$ & $610 \mathrm{mg}$ & $600 \mathrm{mg}$ \\
\hline Haliclona sp. (SPB 3) & $3150 \mathrm{mg}$ & $730 \mathrm{mg}$ & $320 \mathrm{mg}$ \\
\hline Agelas sp. (SPB 4) & $5000 \mathrm{mg}$ & $1030 \mathrm{mg}$ & $300 \mathrm{mg}$ \\
\hline
\end{tabular}

\section{Pengujian Aktivitas Antibakteri}

\section{Plakortis sp. (SPB 1)}

Aktivitas antibakteri melalui zona hambat ditunjukkan pada kedua bakteri uji oleh sampel ekstrak kasar dan fraksi air (Gambar 2) dengan hasil pengukuran zona hambat pada media bakteri $S$. aureus fraksi air ulangan $1(8 \mathrm{~mm})$, ulangan $2(8 \mathrm{~mm})$, dan ulangan $3(7 \mathrm{~mm})$, ekstrak kasar ulangan 1 (8 $\mathrm{mm})$, ulangan $2(9 \mathrm{~mm})$ dan ulangan $3(10 \mathrm{~mm})$ kemudian kontrol (+) (kloramfenikol) ulangan 1 (18 $\mathrm{mm})$, ulangan $2(20 \mathrm{~mm})$, dan ulangan 3 (18 $\mathrm{mm}$ ). Pada media bakteri $E$. coli zona hambat fraksi air ulangan 1 (9 $\mathrm{mm})$, ulangan $2(9 \mathrm{~mm})$, dan ulangan $3(9 \mathrm{~mm})$, ekstrak kasar ulangan 1 (13 $\mathrm{mm})$, ulangan 2 (13 $\mathrm{mm})$, dan ulangan $3(12 \mathrm{~mm})$ kemudian kontrol $(+)$ ulangan $1(21 \mathrm{~mm})$, ulangan $2(20 \mathrm{~mm})$, dan ulangan $3(20 \mathrm{~mm})$.

\section{Liosina sp. (SPB 2)}

Hasil pengamatan jenis spons Liosina sp. dapat dilihat pada Gambar 3, dimana zona hambat pada media bakteri
S. aureus hanya ditunjukkan oleh kontrol (+) saja, ulangan 1 (19 $\mathrm{mm})$, ulangan 2 (21 $\mathrm{mm})$, dan ulangan $3(20 \mathrm{~mm})$. Sedangkan, pada media bakteri $E$. coli zona hambat terdapat pada fraksi air dan kontrol (+). Fraksi air ulangan $1(7 \mathrm{~mm})$, ulangan $2(8 \mathrm{~mm})$, dan ulangan $3(8 \mathrm{~mm})$ kemudian kontrol $(+)$ ulangan $1(18 \mathrm{~mm})$, ulangan 2 (18 $\mathrm{mm})$, dan ulangan 3 (18 $\mathrm{mm}$ ).

\section{Haliclona sp. (SPB 3)}

Hasil pengamatan jenis spons Haliclona sp. dapat dilihat pada Gambar 4, dimana zona hambat pada media bakteri $S$. aureus hanya ditunjukkan kontrol (+) saja yang menunjukkan zona hambat pada ketiga ulangan, ulangan 1 (20 $\mathrm{mm})$, ulangan $2(20 \mathrm{~mm})$, dan ulangan 3 (18 mm). Sedangkan, pada media bakteri $E$. coli zona hambat terdapat pada fraksi air dan kontrol (+). Fraksi air ulangan 1 (9 $\mathrm{mm})$, ulangan 2 (8 $\mathrm{mm})$, dan ulangan $3(7 \mathrm{~mm})$ kemudian kontrol $(+)$ ulangan $1(17 \mathrm{~mm})$, ulangan $2(18 \mathrm{~mm})$, dan ulangan 3 (19 $\mathrm{mm}$ ).

\section{Agelas sp. (SPB 4)}

Hasil pengamatan jenis spons Agelas sp. dapat dilihat pada Gambar 6, dimana zona hambat pada media bakteri $S$. aureus dan $E$. coli pada ketiga ulangan menunjukkan adanya zona hambat pada ekstrak kasar dan kontrol (+). Diameter zona hambat pada media bakteri $S$. aureus ekstrak kasar ulangan $1(7 \mathrm{~mm})$, ulangan $2(7 \mathrm{~mm})$, dan ulangan $3(7 \mathrm{~mm})$ kemudian kontrol (+) ulangan $1(19 \mathrm{~mm})$, ulangan 2 (16 mm), dan ulangan 3 (19 $\mathrm{mm})$. Pada media bakteri $E$. coli zona hambat ekstrak kasar ulangan $1(10 \mathrm{~mm})$, ulangan 2 (12 $\mathrm{mm})$, dan ulangan $3(9 \mathrm{~mm})$ kemudian kontrol (+) ulangan $1(20 \mathrm{~mm})$, ulangan $2(20 \mathrm{~mm})$, dan ulangan 3 (18 $\mathrm{mm})$. 


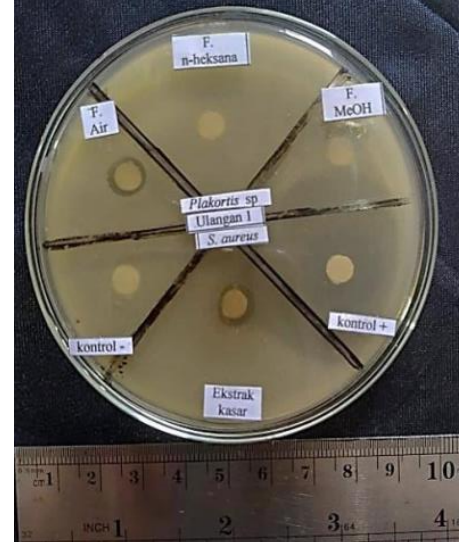

A

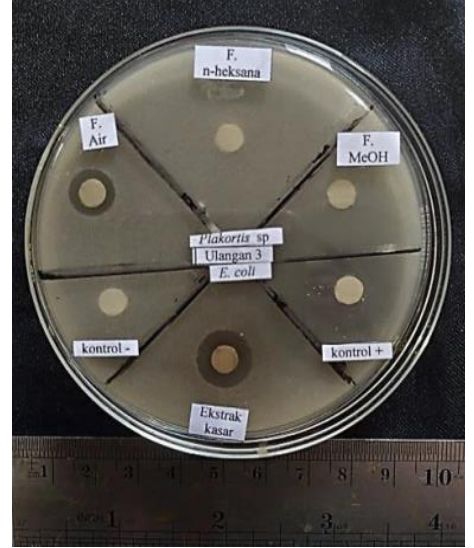

B

Gambar 2. Hasil pengujian antibakteri Plakortis sp. terhadap media (A) S.aures (B) E. coli

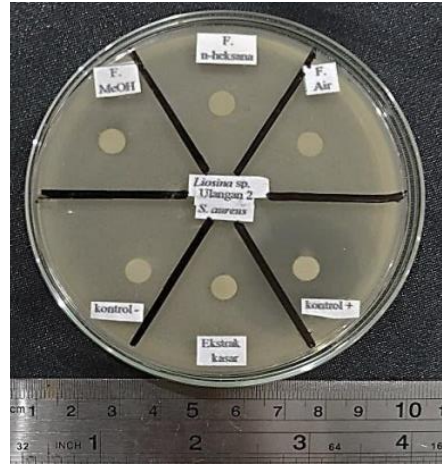

A

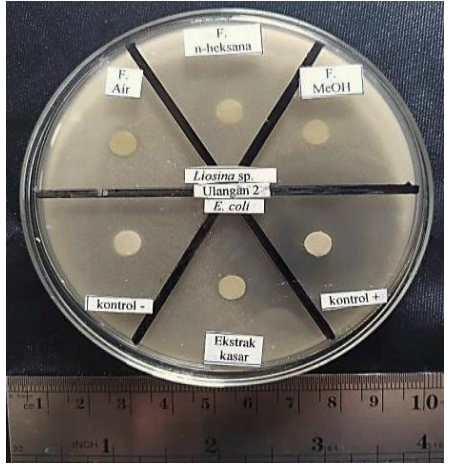

B

Gambar 3. Hasil pengujian antibakteri Liosina sp. terhadap media (A) S.aures (B) E. coli

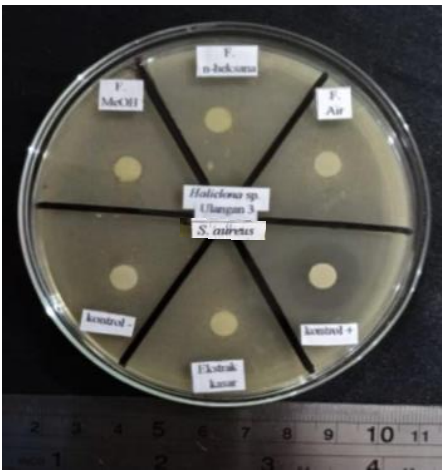

A

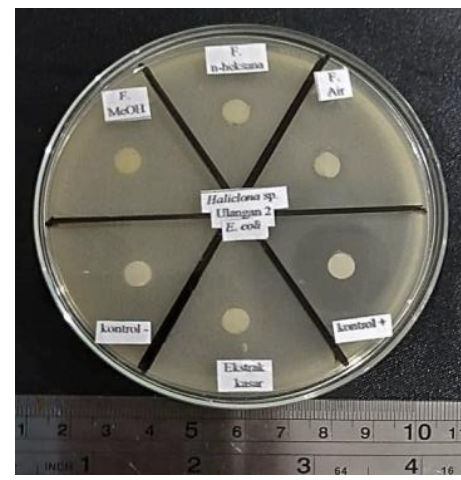

B

Gambar 4. Hasil pengujian antibakteri Haliclona sp. terhadap media (A) S.aures (B) E. coli 


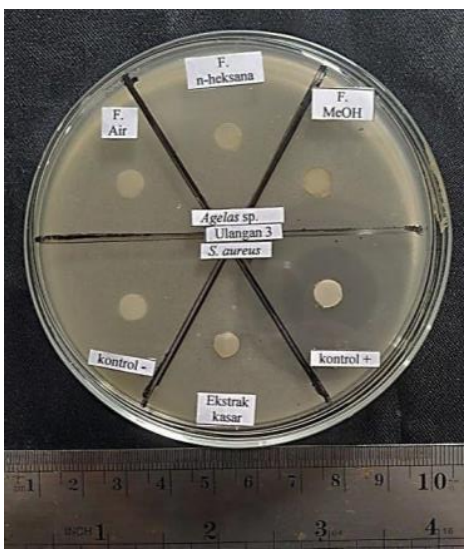

A

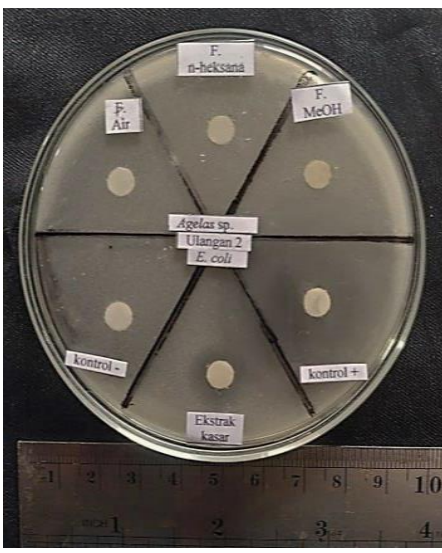

B

Gambar 5. Hasil pengujian antibakteri Agelas sp. terhadap media (A) S.aures (B) E. coli

Tabel 3. Rerata zona hambat spons

\begin{tabular}{|c|c|c|c|c|c|}
\hline \multirow{2}{*}{ Bakteri } & \multirow{2}{*}{ Sampel } & \multicolumn{4}{|c|}{ Rerata zona hambat (mm) } \\
\hline & & $\begin{array}{c}\text { Plakortis sp. } \\
\text { (SPB 1) }\end{array}$ & $\begin{array}{l}\text { Liosina sp. } \\
\text { (SPB 2) }\end{array}$ & $\begin{array}{l}\text { Haliclona sp. } \\
\text { (SPB 3) }\end{array}$ & $\begin{array}{c}\text { Agelas sp. } \\
\text { (SPB 4) }\end{array}$ \\
\hline \multirow{6}{*}{ S.aureus } & Ekstrak Kasar & 9 & - & - & 7 \\
\hline & Fraksi Air & 8,6 & - & - & - \\
\hline & Fraksi Metanol & - & - & - & - \\
\hline & Fraksi N-heksana & - & - & - & - \\
\hline & Kontrol (+) & 18,6 & 20 & 19,3 & 18 \\
\hline & Kontrol (-) & - & - & - & - \\
\hline \multirow{6}{*}{ E.coli } & Ekstrak Kasar & 12,6 & - & - & 10,3 \\
\hline & Fraksi Air & 9 & 7,6 & 8 & - \\
\hline & Fraksi Metanol & - & - & - & - \\
\hline & Fraksi N-heksana & - & - & - & - \\
\hline & Kontrol (+) & 20,3 & 18 & 18 & 18 \\
\hline & Kontrol (-) & - & - & - & - \\
\hline
\end{tabular}

Rerata zona hambat spons terhadap bakteri S. aureus

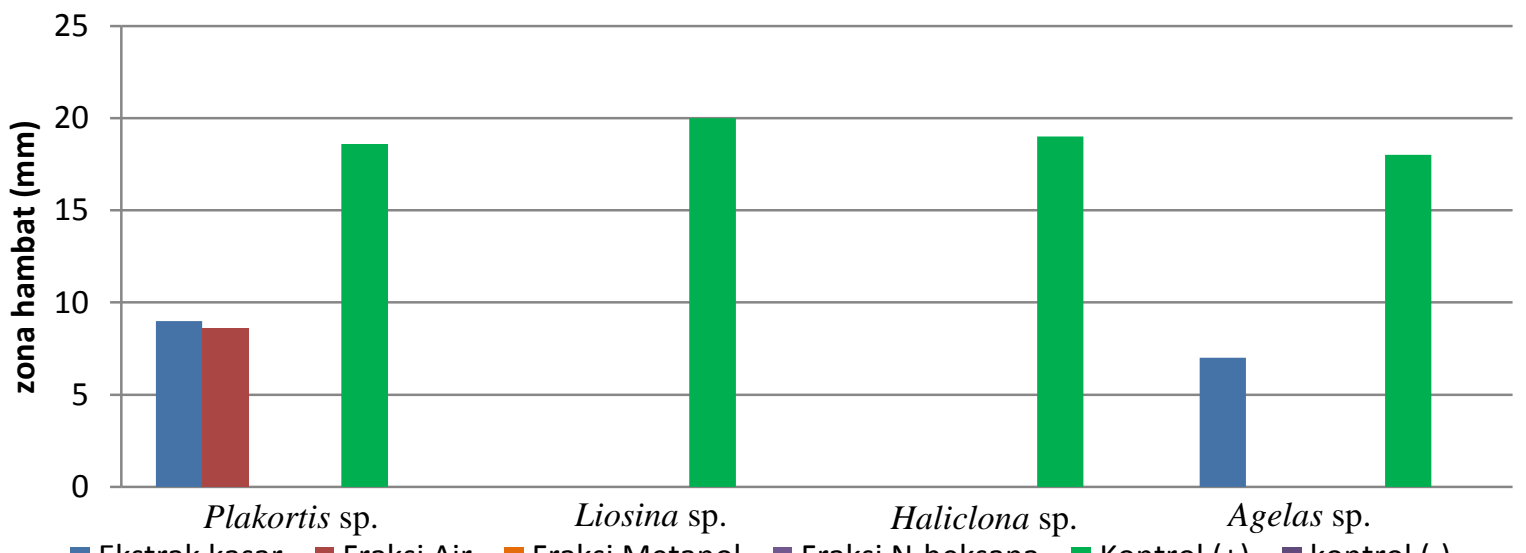

Ekstrak kasar $\square$ Fraksi Air Fraksi Metanol $\square$ Fraksi N-heksana Kontrol (+) a kontrol (-) 


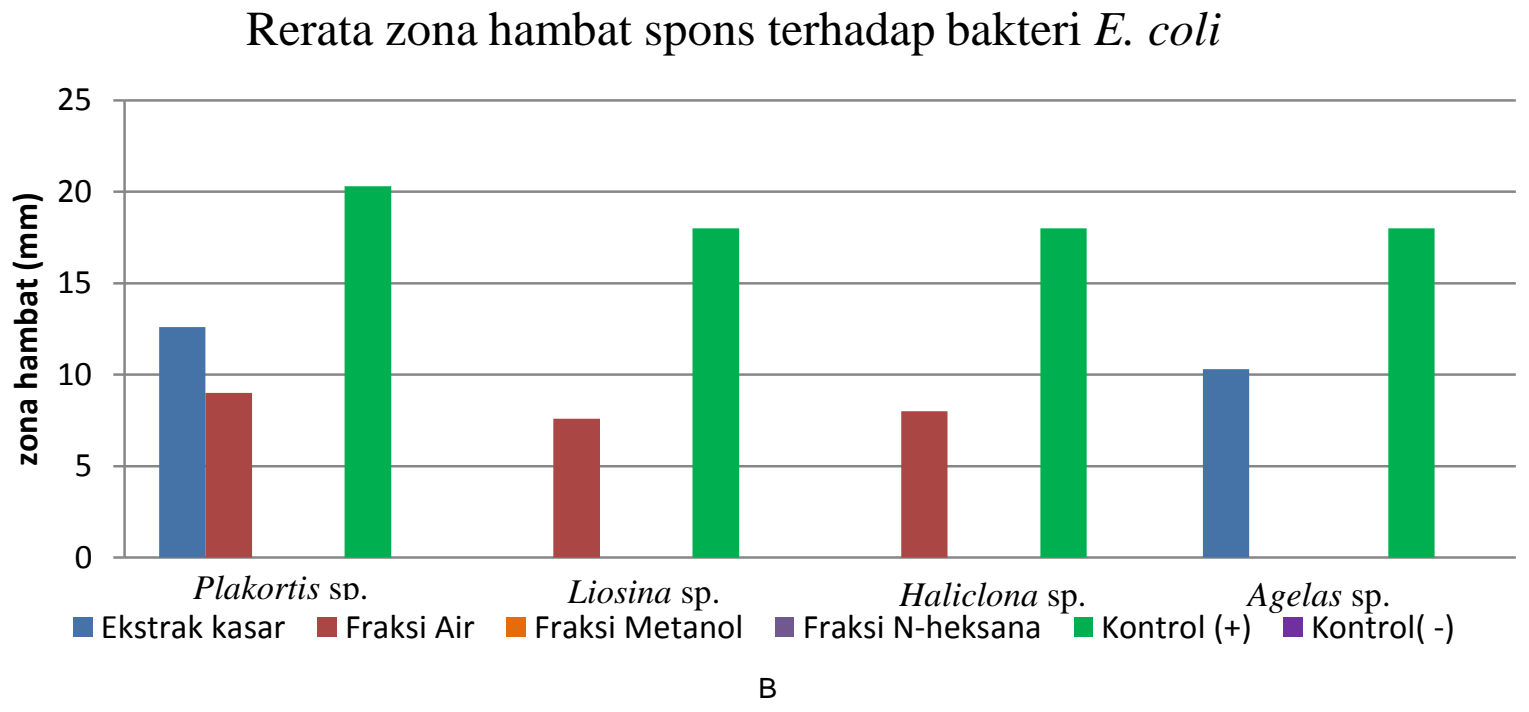

Gambar 6. Grafik rerata zona hambat spons terhadap bakteri (A) S.aures (B) E. coli

Dari data yang ditampilkan pada tabel 3 dapat dilihat bahwa zona hambat yang dihasilkan dari ekstrak kasar maupun fraksi air spons terhadap bakteri $S$. aureus dan E. coli memiliki nilai yang bervariasi namun cenderung lebih rendah nilainya jika dibandingkan dengan zona hambat pada kontrol (+) (kloramfenikol). Menurut Davis dan Stour (1971) dalam Melkianus $d k k$ (2019) kekuatan aktivitas antibakteri dapat digolongkan sebagai berikut, diameter zona hambat $\leq 5 \mathrm{~mm}$ (lemah), 5-10 $\mathrm{mm}$ (sedang), 10-20 mm (kuat) dan $>20 \mathrm{~mm}$ (sangat kuat). Pada tabel 3 Plakortis sp. menunjukkan aktivitas antibakteri yang sedang terhadap bakteri $S$. aureus pada sampel ekstrak kasar $(9 \mathrm{~mm}$ ) dan fraksi air $(8,6 \mathrm{~mm})$ sedangkan pada bakteri E. coli, sampel ekstrak kasar menunjukkan aktivitas antibakteri yang kuat $(12,6 \mathrm{~mm})$ dan pada fraksi air $(9 \mathrm{~mm})$ tergolong sedang.

Pada spons jenis Liosina sp. dan Haliclona sp. keduanya tidak menunjukkan aktivitas antibakteri terhadap bakteri gram (+) S. aureus karena tidak ditemukan zona hambat pada seluruh sampel kecuali kontrol (+) saat dilakukan pengamatan pengujian antibakteri. Namun, pada media bakteri $E$. coli keduanya menunjukkan aktivitas antibakteri yang tergolong sedang pada fraksi air Liosina sp. $(7,6 \mathrm{~mm})$ dan Haliclona sp. (8 mm). Dapat disimpulkan bahwa senyawa antibakteri pada kedua jenis spons terhadap bakteri $E$. coli bersifat polar dan aktifitas antibakteri memiliki spektrum kerja sempit karena tidak dapat menghambat bakteri gram (+) yaitu $S$. aureus (Jolanda $d k k, 2019)$. Ketidak-reaktifan antibakteri terhadap bakteri E. coli pada ekstrak kasar spons jenis Liosina sp. dan Haliclona sp. di lokasi yang sama ditemukan juga pada penelitian yang dilakukan oleh Liem $d k k$ (2019).

Jenis spons Agelas sp. menunjukkan adanya aktivitas antibakteri terhadap kedua bakteri uji pada sampel ekstrak kasar yang tergolong sedang pada bakteri $S$. aureus $(7 \mathrm{~mm})$ dan tergolong kuat pada E. coli $(10,3 \mathrm{~mm})$. Sedangkan pada ketiga fraksi tidak ditemukan aktivitas antibakteri karena tidak terdapatnya zona hambat pada saat pengamatan. Dapat juga diketahui bahwa spons jenis Agelas sp. memiliki spektrum kerja antibakteri yang luas.

Hasil pengamatan pada kontrol (+) menunjukkan zona hambat yang lebih besar dibandingkan dengan ekstrak kasar dan ketiga fraksi terhadap kedua bakteri uji. Penggunaan kontrol (+) pada penelitian ini adalah antibiotik kloramfenikol yang telah diketahui memiliki spektrum kerja yang luas 
dalam menghambat pertumbuhan bakteri (Rahmawati, 2015).

Kontrol (-) yang digunakan adalah metanol 95\% karena pelarut yang digunakan untuk melarutkan larutan uji adalah metanol 95\%. Dari hasil yang ditunjukkan, kontrol (-) tidak memiliki zona hambat pada kedua bakteri uji sehingga dapat diketahui bahwa aktivitas antibakteri yang ditunjukkan oleh ekstrak kasar spons. Plakortis sp. dan Agelas sp. serta fraksi air dari spons Plakortis sp., Liosina sp., dan Haliclona sp. adalah murni senyawa aktif yang terkandung dalam sampel. Dapat dipastikan juga bahwa pelarut yang dipakai sebagai kontrol (-) tidak memberikan pengaruh pada zona hambat yang terbentuk (Jolanda $d k k, 2019$ ).

Dari 4 jenis spons tidak ditemukan adanya aktivitas antibakteri pada fraksi metanol dan n-heksana. Ketidak-reaktifan fraksi tersebut dalam menghambat pertumbuhan bakteri uji menunjukkan bahwa senyawa metobolit sekunder yang larut dalam metanol maupun n-heksana tidak memiliki aktivitas antibakteri (Zakharia $d k k, 2017)$.

Spons yang memiliki aktivitas antibakteri sangat erat hubungannya dengan lingkungan dimana organisme tersebut menetap. Produksi senyawa metabolit sekunder spons akan lebih besar ketika tekanan lingkungannya relatif tinggi, sebaliknya jika tekanan lingkungan relatif rendah maka spons akan menghasilkan senyawa yang kecil (Rinehart, 1992 dalam Opa $d k k, 2018)$. Berdasarkan penelitian yang dilakukan, ekstrak kasar dari spons jenis Plakortis sp. dan Agelas sp. tergolong kuat untuk aktivitas antibakteri, berprotensi untuk dijadikan sebagai bahan obat antibakteri. Sedangkan aktivitas antibakteri spons jenis Liosina sp. dan Haliclona sp. perlu diteliti lebih lanjut untuk mengetahui potensinya sebagai bahan dasar obat. Keempat jenis spons yang telah diuji perlu diteliti lebih lanjut untuk dapat menentukan senyawa antibakteri apa yang terkandung dalam spons tersebut.

\section{Pengujian Aktivitas Anti-UV}

Dari hasil pengujian antibakteri yang telah dilakukan sebelumnya ditunjukkan bahwa sampel ekstrak kasar dan fraksi air adalah sampel yang menghasilkan zona hambat terhadap pertumbuhan bakteri uji. Maka pada pengujian ini, sampel ekstrak kasar dan fraksi air 4 jenis spons diujikan pada alat UV-1800 SHIMADZU spektrofotometer untuk mengetahui serapan sampel pada $\lambda 290-400 \mathrm{~nm}$.

Ekstrak kasar dari spons Plakortis sp. menunjukkan adanya serapan pada $\lambda$ 290-320 nm (UV-B) sebesar $4 \AA$ selanjutnya puncak kedua juga menunjukkan adanya absorbsi UV-A $\lambda$ 320-400 nm dengan nilai absorban tertinggi sekitar $2,7 \AA$ pada $\lambda$ 370$400 \mathrm{~nm}$. Hal yang sama juga ditunjukkan pada fraksi air Plakortis sp, dimana terdapat serapan sebesar $4 \AA$ pada $\lambda 290-320 \mathrm{~nm}$ (UV-B) sedangkan pada $\lambda$ 320-400 nm (UVA) terdapat serapan yang nilai absorbsi tertinggnya $4 \AA$ pada $\lambda 320-330 \mathrm{~nm}$ dan menurun sampai 1,7 $\AA$ dan naik lagi sampai 2,3 A pada $\lambda$ 370-400 nm (Gambar 7).

Ekstrak kasar dari spons Liosina sp. menunjukkan adanya serapan pada $\lambda$ 290$320 \mathrm{~nm}$ (UV-B) sebesar $4 \AA$ selanjutnya pada $\lambda$ 320-400 $\mathrm{nm}$ menunjukkan adanya absorbsi UV-A dengan nilai absorban tertinggi sekitar $4 \AA$ pada $\lambda 330 \mathrm{~nm}$ namun turun drastis pada $\lambda 340 \mathrm{~nm}$ sampai pada nilai absorban $2 \AA$ dan tetap stabil sampai $\lambda 400 \mathrm{~nm}$. Hal yang sama juga ditunjukkan pada fraksi air Liosina sp, dimana terdapat serapan sebesar $4 \AA$ pada $\lambda$ 290-320 nm (UV-B) sedangkan pada serapan UV-A terjadi penurunan sampai $1 \AA$ pada $\lambda 330$ $\mathrm{nm}$ dan tetap konstan sampai $\lambda 400 \mathrm{~nm}$ (UV-A) (Gambar 8).

Ekstrak kasar dari spons Haliclona sp. menunjukkan adanya serapan pada $\lambda$ 290-320 nm (UV-B) sebesar $4 \AA$ selanjutnya pada $\lambda$ 320-400 $\mathrm{nm}$ menunjukkan adanya absorbsi UV-A dengan nilai absorban tertinggi sekitar $4 \AA$ pada $\lambda 320-330 \mathrm{~nm}$ namun turun drastis pada $\lambda 340 \mathrm{~nm}$ sampai pada nilai absorban $1,7 \AA$ dan tetap stabil sampai $\lambda 400 \mathrm{~nm}$. Pada fraksi air Haliclona sp terdapat serapan sebesar $4 \AA$ pada $\lambda$ 290-320 nm (UV-B) sedangkan pada (UVA) terdapat serapan dengan nilai tertinggi 
yaitu $4 \AA$ pada $\lambda 320 \mathrm{~nm}$ dan turun drastis sampai 0,7 $\AA$ di $\lambda$ 330-400 nm (Gambar 9).

Ekstrak kasar dari spons Agelas sp. menunjukkan adanya serapan pada $\lambda$ 290$320 \mathrm{~nm}$ (UV-B) sebesar $4 \AA$ selanjutnya pada $\lambda$ 320-400 $\mathrm{nm}$ menunjukkan adanya absorbsi UV-A dengan nilai absorban tertinggi sekitar $4 \AA$ pada $\lambda 320-340 \mathrm{~nm}$ namun turun drastis pada $\lambda 350 \mathrm{~nm}$ sampai pada nilai absorban $1,7 \AA$ dan tetap stabil sampai $\lambda 400 \mathrm{~nm}$. Pada fraksi air Agelas sp, terdapat serapan sebesar $4 \AA$ pada $\lambda 290$ $320 \mathrm{~nm}$ (UV-B) sedangkan $\lambda$ 320-400 nm (UV-A) terdapat serapan dengan nilai tertinggi yaitu $4 \AA$ pada $\lambda 320-330 \mathrm{~nm}$ dan turun drastis sampai $0,3 \AA$ di $\lambda$ 340-400 nm (Gambar 10).

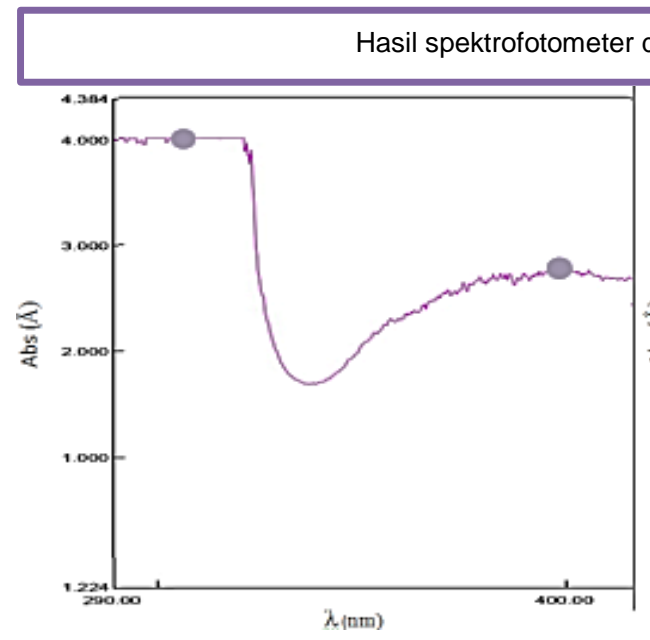

A

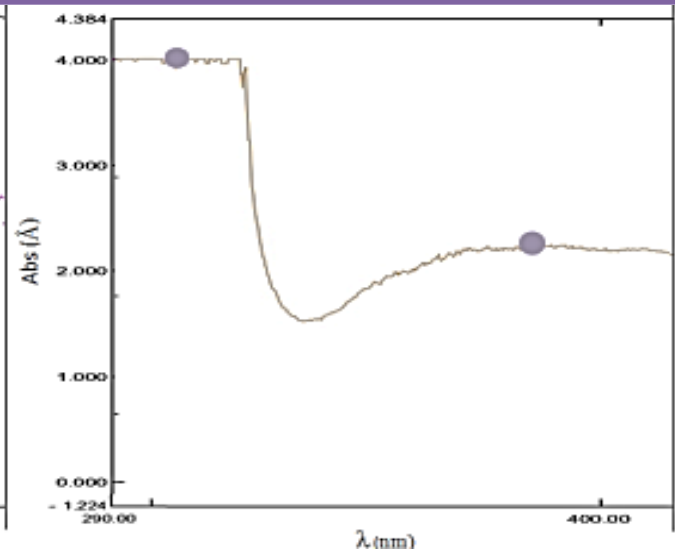

B

Gambar 7. (A) Hasil spektrofotometer sampel ekstrak kasar Plakortis sp. (B) Hasil spektrofotometer sampel fraksi air Plakortis sp.

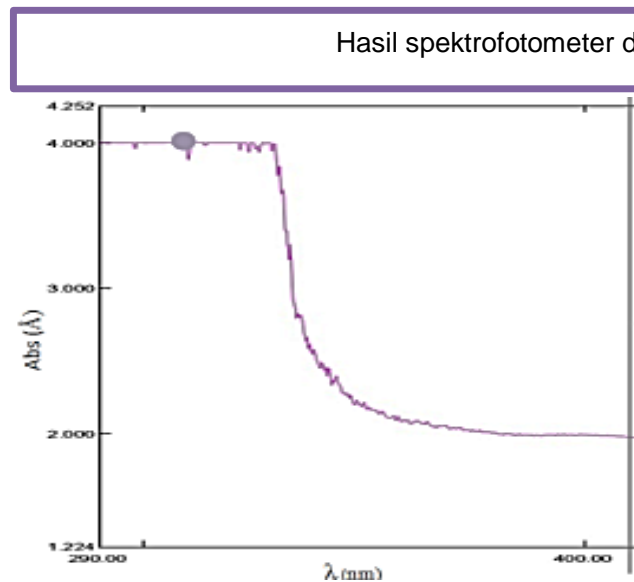

A

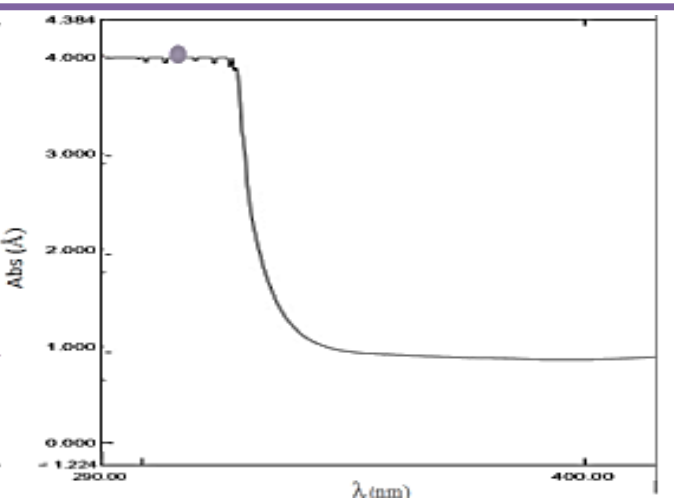

B

Gambar 8. (A) Hasil spektrofotometer sampel ekstrak kasar Liosina sp. (B) Hasil spektrofotometer sampel fraksi air Liosina sp. 


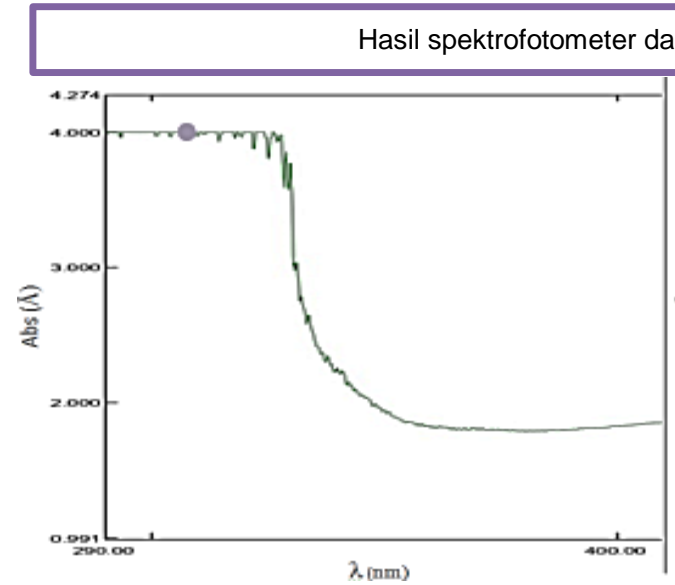

A

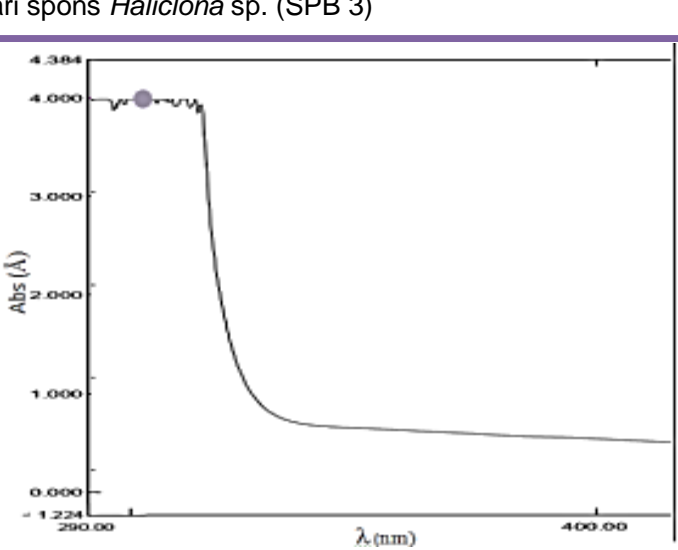

$\mathrm{B}$

Gambar 9. (A) Hasil spektrofotometer sampel ekstrak kasar Haliclona sp. (B) Hasil spektrofotometer sampel fraksi air Haliclona sp.

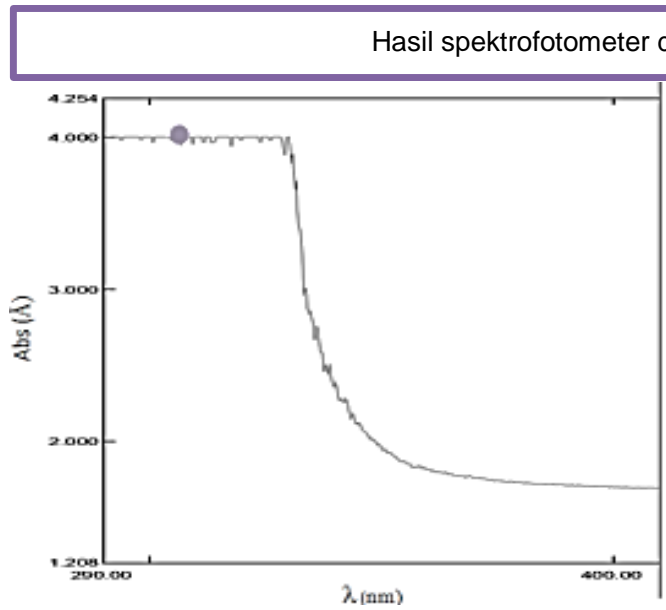

A

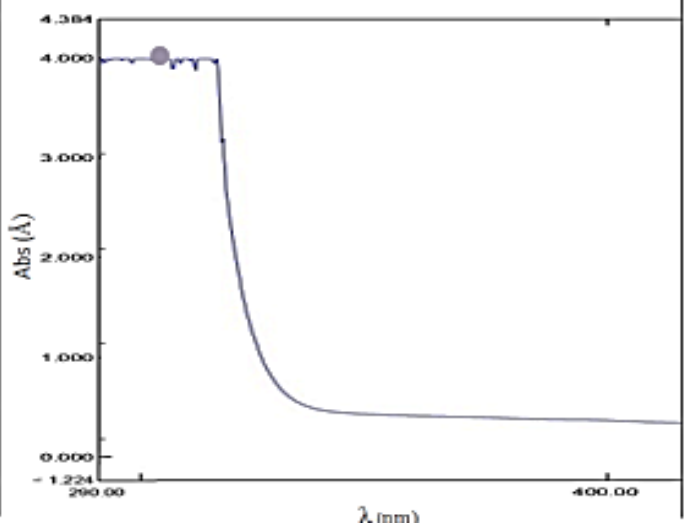

B

Gambar 10. (A) Hasil spektrofotometer sampel ekstrak kasar Agelasp. (B) Hasil spektrofotometer sampel fraksi air Agelas sp.

Berdasarkan pengujian melalui UV spektrofotometer ditunjukkan bahwa sampel ekstrak kasar dan fraksi air keempat jenis spons yaitu Plakortis sp., Liosina sp., Haliclona sp., dan Agelas sp. mampu mengabsorbsi UV-A dan UV-B dengan nilai serapan UV-B ( $\lambda$ 290-320 nm) seluruh sampel adalah $4 \AA$. Sedangkan untuk UV-A $(\lambda \quad 320-400 \quad \mathrm{~nm}$ ) seluruh sampel menunjukkan nilai serapan tertinggi pada $\lambda$ 320-330 nm dengan nilai $4 \AA$ dan mengalami penuruann pada $\lambda 340-400 \mathrm{~nm}$ dengan nilai serapan paling kecil ditunjukkan pada fraksi air spons Agelas sp. sebesar 0,3 A. Keempat jenis spons menunjukkan kemampuan dalam menghasilkan senyawa anti-UV sebagai bentuk pertahanan diri terhadap paparan sinar matahari. Namun perlu dilakukan penelitian lebih lanjut untuk menentukan senyawa anti-UV yang terkandung dalam spons sebagai bahan pembuatan tabir surya.

\section{KESIMPULAN}

Berdasarkan penelitian dapat disimpulkan bahwa

1. Ekstrak empat jenis spons berhasil diperoleh dari Perairan Pangalisang Bunaken dan fraksi yang didapatkan melalui teknik partisi yaitu fraksi air, fraksi metanol dan fraksi n-heksana.

2. Aktivitas antibakteri spons jenis Plakortis sp. dan Agelas sp ditemukan pada kedua bakteri uji sedangkan spons 
Liosina sp. dan Haliclona sp. hanya ditemukan pada bakteri Escherichia coli.

3. Pengujian anti-UV pada UV spektrofotometer menunjukkan bahwa sampel ekstrak kasar dan fraksi air keempat jenis spons dapat menyerap UV-B dan UV-A.

\section{DAFTAR PUSTAKA}

Allen, G dan Steene, R. 2007. Indo-Pasific Coral Reef Field Guide. Tropical Reef Research, Singapore. ISBN: 981-005687-7

Archer, G. L. 1998. Staphylococcus aureus: a well-armed pathogen. Reviews of Infectious Diseases, 26(5): hal. 11791181.

Gosliner, T., Behrens, D. W., dan Williams, G. C. 1996. Coral reef animals of the Indo-Pacific: animal life from Africa to Hawaii exclusive of the vertebrates. Sea Challengers.

Jolanda, S., Wewengkang, D. S., dan Jayanto, I. 2019. Aktivitas antimikroba ekstrak dan fraksi alga (Halimeda opuntia) terhadap Escherichia coli, Staphylococcus aureus dan Candida albicans. Pharmacon, 8(2): hal. 57-65.

Liem, J., Bara, R., Sumilat, D., Warouw, V., Losung, F., dan Wantasen, A. 2019. Bioprospeksi antibakteri beberapa jenis spons dari Perairan Pangalisang Bunaken. Jurnal pesisir dan laut tropis, 1(1): hal. 7-12.

Marzuki, I. 2018. Eksplorasi spons indonesia: seputar kepulauan spermonde. Nas Media Pustaka, Makassar.

Mehbub, M., Lei, J., Franco, C., dan Zhang, W. 2014. Marine sponge derived natural products between 2001 and 2010: Trends and opportunities for discovery of bioactives. Marine drugs, 12(8): hal. 4539-4577.

Melkianus, B., Fatimawali, F., dan Sudewi, S. 2019. Uji aktivitas antibakteri ekstrak kulit buah manggis (Garcinia mangostana L.) Terhadap bakteri Klebsiella pneumonlae. Pharmacon, 8(1).
Melliawati, R. 2015. Escherichia coli dalam kehidupan manusia. BioTrends, 4(1): hal. 10-14.

Murniasih, T. 2003. Metabolit sekunder dari spons sebagai bahan obatobatan. Jurnal Oseana (3): hal. 27-33.

Opa, S., Bara, R., Gerung, G., Rompas, R., Lintang, R., dan Sumilat, D. 2018. Uji aktivitas antibakteri fraksi n-heksana, metanol dan air dari ascidian Lissoclinum sp. Jurnal pesisir dan laut tropis, 1(1): hal. 69-80.

Rahmawati, M. 2015. Uji Aktivitas Antimikroba Ekstrak Etanol dan Air Rimpang Pacing (Costus spiralis) Terhadap Bakteri Escherichia coli, Shigella dysenteriae, Salmonella typhimurium, Bacillus subtilis, Staphylococcus aureus Serta Fungi Candida albicans [skripsi]. Fakultas Kedokteran dan IImu Kesehatan, Universitas Islam Negeri Syarif Hidayatullah, Jakarta.

Thakur, N. L., dan Müller, W. E. 2004. Biotechnological potential of marine sponges. Jurnal

Current Science, 86(11): hal. 1506-1512.

Warbung, Y. 2013. Daya hambat ekstrak spons laut Callyspongia sp terhadap pertubuhan bakteri Enterococci faecalis. e-GIGI, 1(2).

Warouw, V. dan Losung, F. 2015. Potensi Substans Anti-uv Dari Serangga Laut Family Gerridae Di Tasik Ria Mokupa Manado, Sulawesi Utara. Jurnal LPPM Bidang Sains dan Teknologi, 2(2): hal. 95-102.

Zakaria, Z., Soekamto, N. H., dan Firdaus, F. 2017. Aktivitas antibakteri dari fraksi artocarpus integer (Thunb.) Merr. Dengan metode difusi agar (Antibacterial Activity of Artocarpus Integer (thunb.) Merr. Fraction by Difusi Agar Method). Jurnal Industri Hasil Perkebunan, 12(2): hal. 1-6. 